\title{
Rediscovering Partisanship as the Long Term Force in the Vote Decision
}

\author{
Michael D. Martinez \\ University of Florida
}

\begin{abstract}
While partisanship is commonly conceived as the long term force in the voting decision, most models of voter choice include contemporaneous measures of partisanship, as well as issue preferences and retrospective evaluations as explanatory variables. In this paper, I use four multiyear panel studies spanning half a century to examine how well prior partisanship predicts future vote. Prior partisanship is strongly correlated with later vote choice, but that relationship is weaker during periods of party change, for younger voters and those who do not see differences between the parties, and in the face of strong short term forces. Despite evidence of the endogeneity of partisanship, we should also not lose sight of its long-term value as a predictor of vote choice.
\end{abstract}

The authors of The American Voter conceptualized partisanship as the long term force in the voting decision, as most people learned partisanship relatively early in life, primarily from their parents, and maintained the same identification as they entered and progressed through their adult years. Survey data from the 1950s were replete with respondent references to the hard times under Hoover and to the recovery under the New Deal (Campbell, et al. 1960, 151-185), underscoring the picture of most people having been raised a Democrat (or Republican), maintaining that allegiance through the tumultuous years of young adulthood, and hardening that allegiance as one aged, at least in a steady-state party system (Converse 1976). The Michigan model portrayed partisanship as shaping issue preferences, perceptions of candidates, and evaluations of the "nature of the times", which in turn would structure the vote choice. As a result, stronger partisans tended to have more consistent issue preferences and perceptions about their party's candidate, greatly simplifying their vote choices. While candidates would change from one election to the next, as Stevenson, Kennedy, Johnson, Humphrey, McGovern, Carter, Mondale, Dukakis, Clinton, Gore, and Obama all shared the Democratic Party label, each had different backgrounds, abilities, and political liabilities. Issues vary over time, as well, as few voters today know where the islands of Quemoy and Matsu are nor why they were so salient in past presidential elections (White 1961), and few voters in those elections long ago could have imagined that gay marriage would be a salient issue today that mobilizes substantial numbers of voters on both sides. The variability of candidates and issues over time and across ballots made them "short term" forces in elections. Those short term forces were sometimes weak, or offsetting in the aggregate, but they were sometimes strong enough to cause the electoral outcome to deviate from the partisan alignment of the day. (Campbell, et al. 1960, 531-538; Miller, et al. 1976) While The American Voter acknowledged that partisanship was not immutable (Campbell, et al. 1960, 149-167), the relative stability of party identification at the individual level rendered it the "long term" force in an election. Candidates and issues would come and go, as would voters' attitudes about them, but voters' identifications with the Democratic and Republican parties are almost as resilient as the parties themselves.

Later models that included partisanship as an endogenous variable suggested that it was not the "unmoved mover", noting its responsiveness to varying degrees to retrospective 
evaluations (Fiorina 1981), issue preferences (Page and Jones 1979; Franklin and Jackson 1983; Highton and Kam 2011; Niemi and Jennings 1991), and behavioral reinforcement (Markus and Converse 1979) at the individual level, and to presidential popularity and perceptions of economic conditions at the aggregate level (MacKuen, et al. 1989). Two and four year panels showed individual level movement between partisan categories, especially between "strong" and "weak" identifications with the same party, as well as into and out of Independent categories (Martinez and Gant 1990), and longer term panels showed that young people who had not yet developed a long history of behavioral reinforcement were more malleable in their partisan identifications over time (Niemi and Jennings 1991). Still, partisanship remains remarkably stable in contrast to other political orientations (Converse and Markus 1979; Jennings and Niemi 1981, 48-75; Johnston 2006), and even after years of holding countervailing issue positions, vestiges of parental partisanship remain detectable among some young adults (Niemi and Jennings 1991). In sum, while partisanship is not set in stone by any means, it remains quite stable compared to other political beliefs. Thus, despite evidence of some endogeneity, partisanship's relative degree of stability keeps it closer to the mouth than to the tip of the funnel of causality in the voter decision making.

While we think of partisanship as the long term force on the voter choice, most models of voter choice include contemporaneous measures of partisanship, issue preferences, and retrospective evaluations as predictors. While the relative influence of those variables depends on the specifications of the model (see Page and Jones 1979, in contrast to Markus and Converse 1979), the use of contemporaneous measures on both sides of the equation obscures our understanding of the value of the partisanship as a long term predictor of the vote choice. Most likely, contemporaneous multivariate specifications underestimate the long term influence of partisanship because the resulting estimates only capture the direct effects of partisanship, and they conceal the indirect effects of partisanship through issues and candidate evaluations. In other words, if in the long run, partisanship conditions issue preferences and candidate evaluations, controlling for contemporaneous values of those variables in multivariate models will only show the direct influence of partisanship on the vote choice, ceteris paribus, as opposed to its total (direct and indirect) long-term influence. As of this writing, no one can be certain who the Democratic presidential nominee will be in 2016 (or 2020), nor who will emerge as her or his Republican challenger, nor which issues will emerge as the most salient in the election campaigns to come. Most observers are, however, more confident that there will be Democratic and Republican nominees, and that they will be the principal contenders for the presidency. Moreover, we expect that most of today's self-identified Democrats will vote for the Democratic candidate and most self-identified Republicans will vote for the Republican candidate, whomever the candidates may be. A few analyses that have modeled voter choice as a function of lagged party identification have suggested that lagged party identification is a strong long term predictor of vote choice (Miller and Shanks 1996, 356-360; Green, et al. 2002). But, how confident can we be in that prediction, and what affects that confidence? Even with the understanding that partisanship is endogenous, its role in shaping future behavior is still important, as parties and candidates base their long term strategies, in part, on the playing field that exists years before any given election. 
Thus, the central questions for this paper are

(1) how well does an individual's partisanship predict her or his future vote choice, and

(2) what factors structure that relationship?

\section{The role of partisan context}

Two of the main architects of The American Voter model also articulated that key implications of the model held only in a stable party system. As the sands shifted beneath the New Deal party system, the resulting dealignment altered both the basic reinforcement processes that usually strengthened partisanship with age (Converse 1976) and weakened the intergenerational transmission of partisanship from an older cohort to its offspring (Miller and Shanks 1996, 151-185). As civil rights and "new politics" issues transformed the support bases of the parties (Carmines and Stimson 1989), they evidently weakened the cues from parents to their young adult children, as well as the behavioral cues associated with one's own vote. Taken together, the changing party coalitions, perceptions of the salience of issues along with the bases of issue conflict, and levels of split ticket voting (Aldrich and Niemi 1995) suggested a devaluation of past party identification as a predictor of the current vote choice in the late 1960s and 1970s.

Almost as suddenly as the electorate dealigned from the parties, partisanship resurged. Following the nadir of partisan voting the in 1972 presidential election, the proportion of strong identifiers and partisan leaners started to rebound, at the expense of weak partisans and pure independents, respectively, and there was a "revival" of partisan voting at the presidential level. (Bartels 2000) The "revival" of partisan voting in Congressional races came later and without quite as much force, but still suggested that partisanship was regaining some of its lost strength as a meaningful cue in the voting booth. By 2004, in terms of its effect on presidential vote choice, partisanship was as strong as it had ever been in the history of the American National Election Studies. While there was a slight retrenchment in 2008, the level of partisan voting was still much higher than existed in the dealignment era (Weinschenk 2013), and hardly indicative of anything resembling "post-partisanship" in the electorate, even if the winning candidate adopted the theme (Ceaser, et al. 2009). In addition, split ticket voting had fallen (Stonecash 2006), and the alignment between partisanship, ideology, and issue preferences at the individual level had strengthened (Bafumi and Shapiro 2009).

Parties change over time (Miller and Schofield 2003) and as they do, the popular understanding of the meanings of their labels also changes. As the Democratic and Republican parties undergo shifts, we would expect to see that the long term force of identification with them would become less relevant in shaping voter choice. But once the parties have settled into positions onto the new playing field, we should expect to see that partisan identification would regain some of its efficacy as a long term force on voter choice. Indeed, in validating his more general argument about the trend of partisan voting over time, Bartels $(2000,46-49)$ found that 
the effect of partisanship (lagged two years) on voter choice was generally higher in 1960 and 1992 than in 1976, when the parties were still struggling with "new politics" issues.

\section{The role of Political Socialization}

Not only do the parties change over time, but potential party identifiers also change over the life cycle. Generally speaking, as people become older, their identification with a political party strengthens (Converse 1976; Lewis-Beck, et al. 2008, 145-150), as does party identification's stability (Jennings and Markus 1984) and its association with issue preferences (Niemi and Jennings 1991). Moreover, as people learn and reinforce their own partisanships, party identification's potential for affecting votes in the future should also increase. Using long panels that spanned thirty-two years (from 1965 to 1997), Jennings and Stoker (2009) found that lagged party identification had increasing effects on vote choice among both youth and their parents in later waves of the panels. In short, as people age and their partisan attitudes stabilize, partisanship becomes a more reliable predictor of vote choice in later elections.

\section{Hypotheses}

Taken together, the extant literature suggests that partisanship should be a strong predictor of future voter choice, and that its efficacy as a predictor will vary across political contexts and across individuals. Lagged partisanship will be a stronger predictor of voter choice when the parties themselves are in a steady-state, that is, when they are not undergoing major transformations of identity and alignment with social groups. Moreover, lagged partisanship is expected to be a stronger predictor of voter choice among older people, who have had longer to discover their own issue preferences and align them with their partisanships, and among people who see important differences between the parties (see Jennings and Stoker 2009, 9-10).

I exploit the four major multi-year American National Election Study panel studies (1956-58-60, 1972-74-76, 1992-94-96, and 2000-02-04) to examine the relationship between lagged partisanship on contemporary vote choice. ${ }^{1}$ Accidents of history resulted in these panels ending in years in which there were no major third party presidential candidates (simplifying the analysis) and in different party system contexts, with the dealignment of the 1970s serving as the contrast to the stable system at mid-century and the resurgent partisanship of the beginning of the new century. The traditional measure of party identification is a seven-point scale that is presumed to be ordinal, ranging from "Strong Democrat" through partisan independence to "Strong Republican" (Campbell, et al. 1960, 121-128; Lewis-Beck, et al. 2008, 112-116), so the appropriate measure of association between partisanship and dichotomous vote choice is Kendall's Tauc. (Blalock 1972, 421-423)

$\mathrm{Tau}_{\mathrm{c}}$ theoretically ranges from -1 (a perfect negative association) through 0 (no association) to +1 (a perfect positive association). In order to illustrate what different levels of $\mathrm{Tau}_{\mathrm{c}}$ look like, Table 1 presents the crosstabulations between presidential vote choice as reported in 1960 and party identification measured contemporaneously and with two- and four-year lags. In this table, identifiers with other parties are excluded, as are those who reported not voting or voting for someone other than Kennedy or Nixon in 1960. 
As expected, the top panel of Table 1 shows that partisanship measured in 1956 is a strong but imperfect predictor of presidential vote choice four years later. Strong partisans in 1956 were quite loyal to their party's nominee in 1960, as only 5.2\% of strong Republicans and $14.7 \%$ of strong Democrats defected to vote for the rival party's nominee. Leaning Democrats were about as loyal as Weak Democrats, and Leaning Republicans were more loyal than Weak Republicans (Keith, et al. 1986), while 1956 Independents split nearly down the middle in the stunningly close election four years later. This positive but imperfect relationship is summarized with a $\mathrm{Tau}_{\mathrm{c}}$ statistic of .653. In the middle panel, depicting the relationship between party identification measured in 1958 and voter choice in 1960, the Tau $\mathrm{Tat}_{\mathrm{c}}$ stastic increases slightly to .685 , reflecting the ordinality of the relationship, as Leaning Republicans in 1958 were less loyal to Nixon two years later than were Weak Republicans. The bottom panel depicts the relationship between party identification and voter choice measured contemporaneously in 1960, when partisans of both parties (but especially Republicans) were very loyal soldiers in the voting booth. That strong loyalty on both sides is reflected in a Tau statistic of .765. Not surprisingly, contemporaneous measures produce the strongest associations, as the relationship between current partisanship and voter choice could very well be the result of reciprocal effects of the two variables on one another. But the main point of Table 1 is that the association of lagged partisanship and later voter choice is still quite strong, and the longer time lag (four years as opposed to two years) weakens the association, but not by much. ${ }^{2}$

\section{Political Context and the Long-term effect of Partisanship on Voter Choice}

We expect that the long term effects of partisanship on voter choice will be weaker during the periods when parties are redefining themselves, and the 1976 election serves as the illustrative case in this analysis. New politics issues (including civil rights, women's rights, and abortion) were emerging as issues that were beginning to crosscut the traditional social welfare dimension that had shaped the US two-party system since the 1930s realignment (Miller and Levitan 1976), just as Vietnam and Watergate had injected a strong dose of distrust in both the Democratic and Republican Parties. (Craig 1985) By the end of the century, the two parties seem to have had settled into a new alignment, and voters' issue preferences on those issues also seemed to align with their party preferences. (Bafumi and Shapiro 2009)

That expectation is borne out nicely in Figure 1, which shows the Tau $\mathrm{u}_{\mathrm{c}}$ statistics for the association between voter choice in four presidential elections corresponding to the end of ANES panel studies and party identification (measured with a four-year lag, a two year lag, and contemporaneously). First, looking across the columns, there is a consistent increase in the association between partisanship and voter choice as the lag in measuring partisanship is reduced from four years to two years to zero. As we saw in Table 1, partisanship's strength as a predictor of voter choice is increased as the time interval between its measurement and the vote choice is reduced. Second, and more directly relevant for this analysis, the long term force of partisanship on voter choice was, as expected, weakest in the 1970s, but rebounded with gusto by the 1990s and 2000s. Indeed, the association between party identification as measured in 1992 with voter choice in 1996 (a four year interval) was as strong as the contemporaneous association of party identification and voter choice in 1976. The links between partisanship and voter choice had 
Table 1: Vote Choice in 1960 and Party Identification

Party Identification in $1956\left(\mathrm{Tau}_{\mathrm{c}}=.653\right)$

$\begin{array}{llllll} & & \text { Lean } & & \text { Str } \\ \text { Str Dem } & \text { Weak Dem } & \text { Lean Dem } \quad \text { Ind } \quad \text { Rep } \quad \text { Weak Rep } & \text { Rep }\end{array}$

$\begin{array}{lccccccc}\text { Kennedy } & 85.3 & 70.5 & 69.4 & 49.5 & 18.4 & 26.7 & 5.2 \\ \text { Nixon } & 14.7 & 29.5 & 30.6 & 50.5 & 81.6 & 73.3 & 94.8 \\ & & & & & & & \\ \text { Number of Cases } & 231 & 234 & 72 & 103 & 98 & 165 & 172\end{array}$

Party Identification in $1958\left(\mathrm{Tau}_{\mathrm{c}}=.685\right)$

$\begin{array}{lccccccc}\text { Kennedy } & 83.0 & 70.8 & 65.6 & 44.0 & 24.3 & 13.8 & 4.7 \\ \text { Nixon } & 17.0 & 29.2 & 34.4 & 56.0 & 75.7 & 86.2 & 95.3 \\ & & & & & & & \\ \text { Number of Cases } & 377 & 284 & 90 & 100 & 74 & 261 & 190\end{array}$

Party Identification in $1960\left(\mathrm{Tau}_{\mathrm{c}}=.765\right)$

$\begin{array}{lccccccc}\text { Kennedy } & 89.5 & 71.5 & 86.8 & 48.1 & 11.8 & 12.1 & 0.0 \\ \text { Nixon } & 10.5 & 28.5 & 13.2 & 51.9 & 88.2 & 87.9 & 100.0 \\ & & & & & & & \\ \text { Number of Cases } & 342 & 340 & 76 & 129 & 110 & 231 & 213\end{array}$

Entries are column percentages based on author's calculations from the 1956-58-60 ANES Panel Study.

weakened a little in 2004, but the association between partisanship measured in 2002 and voter choice in 2004 (a two year lag) was still stronger than the contemporaneous association of party identification and voter choice in 1976. The rebound in the long term effect of party identification on voter choice is yet another indication that rumors of partisanship's death in the 
1970s were, to say the least, premature. The long term force of partisanship is back. (Bartels 2000, Weinschenk 2013)

Figure 1: $\mathrm{Tau}_{\mathrm{c}}$ correlations between Voter Choice ( $\mathrm{t}$ ) and Partisanship (at t-4, t-2, and t)

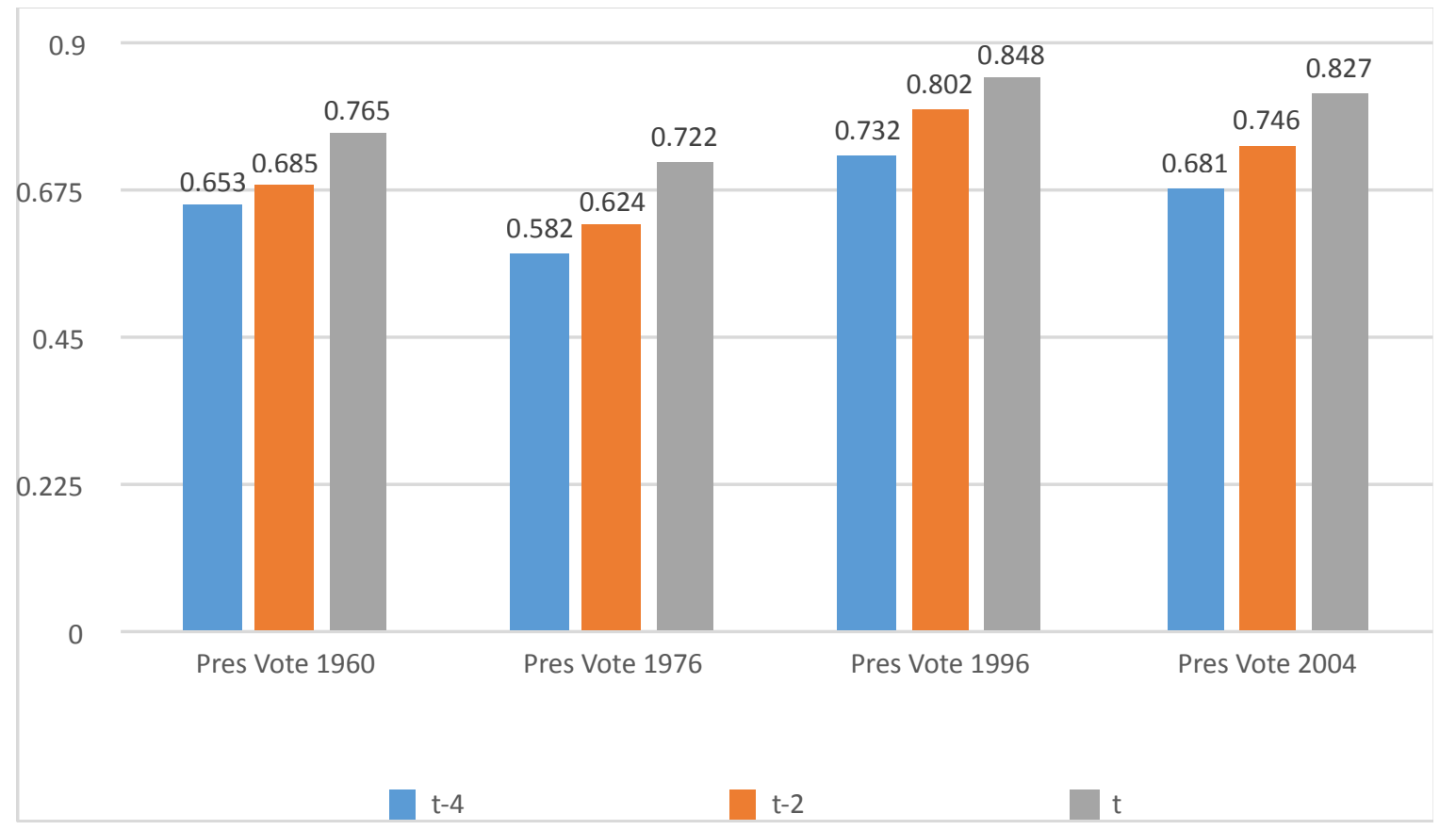

\section{Age effects on Partisanship as a Long-term force}

Over the life cycle, people gradually begin to align their partisanship and issue preferences, and the multiple opportunities to behaviorally reinforce one's party identification in the voting booth generally strengthen a person's identification with a party. Thus, we would expect that, in any given election year, the association between lagged party identification and current voter choice would be stronger among older voters than among younger ones. For the most part, that expectation is supported in Figures $2 \mathrm{a}$ and $2 \mathrm{~b}$, which shows the Tau statistics between lagged partisanship and voter choice for different age groups (as measured in the presidential election year). Figure $2 \mathrm{a}$, which depicts the associations for partisanship lagged two years, illustrates that the association is weakest among voters under the age of 35 and strongest among voters 50 and over in each of the four election years. ${ }^{3}$ Figure $2 \mathrm{~b}$, which depicts partisanship lagged four years, the same pattern is observed in 1960 and in 2004 . However, in 1976, middle-aged voters displayed a stronger association than older voters, and (somewhat inexplicably) in 1996, younger voters had a higher association between partisanship in 1992 and voter choice in 1996. Nevertheless, in six of the eight comparisons in the two figures, the expected pattern across age groups holds 
Figure 2a: Tau correlations between Voter Choice ( $\mathrm{t}$ ) and Partisanship ( $\mathrm{t}-2)$ by Age Group

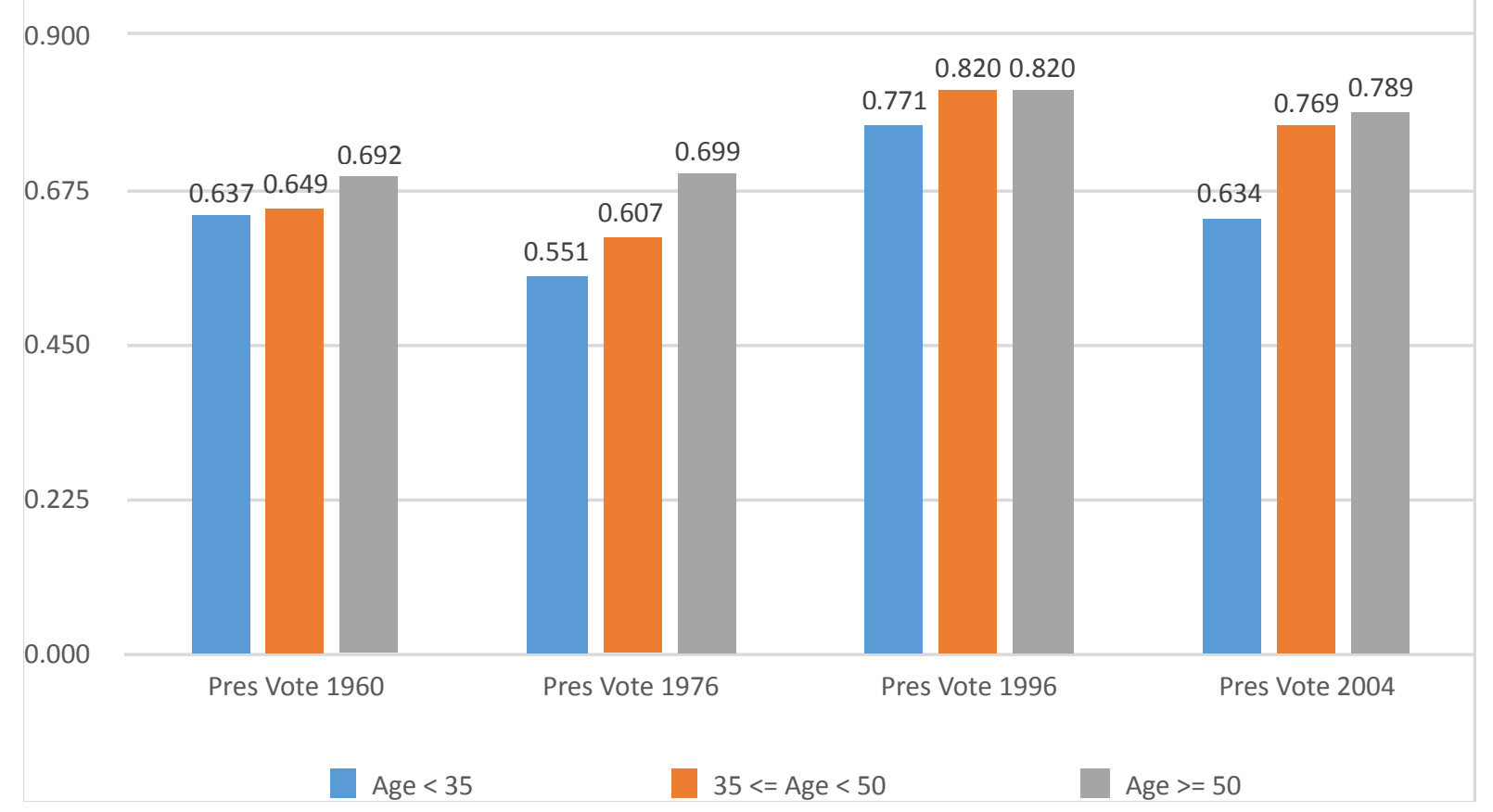

Figure 2b: Tau $\mathrm{c}_{\mathrm{c}}$ correlations between Voter Choice ( $\mathrm{t}$ ) and Partisanship (t-4) by Age Group

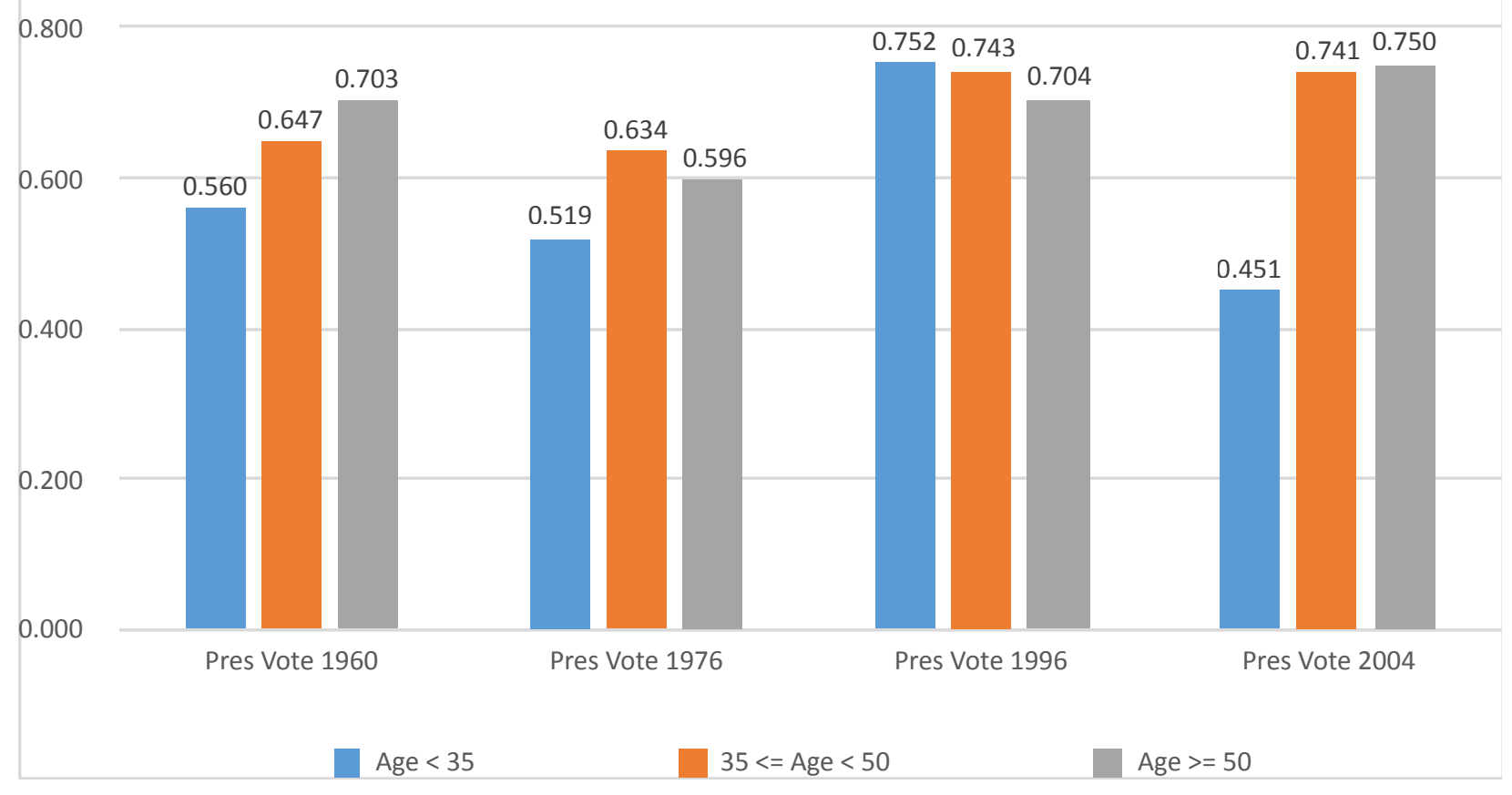




\section{Perceptions of Important Differences between the Parties}

While partisanship was originally conceptualized primarily as an affective attachment to a political party (Campbell, et al. 1960, 121; Green, et al. 2002), there is substantial evidence that a cognitive understanding of the differences between the parties magnifies the relationship between partisanship and voter choice. (Craig and Martinez 1989, Jennings and Stoker 2009) That leads us to expect that the long term effect of partisanship on the vote choice will be stronger among voters who see important differences between the parties than for those who do not. The data in Figures $3 \mathrm{a}$ and $3 \mathrm{~b}$ bear that out, and do so quite forcefully. In each of the four election years, the association between lagged partisanship and current vote choice is much stronger among those who perceive important differences between the parties. Cognitive recognition of the party differences even appears to have a stronger effect on the relationship than context does, as voters who perceived party differences in 1976 had a stronger association between lagged partisanship and current vote choice than voters in any year who did not perceive important differences between the parties. These relationships hold whether one considers partisanship lagged two years (in Figure 3a) or four years (in Figure 3b), and demonstrate that when belief underscores affect, the long term effect of partisanship can be very strong.

Figure 3a: $\mathrm{Tau}_{\mathrm{c}}$ correlations between Voter Choice (t) and Partisanship ( $\left.\mathrm{t}-2\right)$ by Perceptions of Party Differences

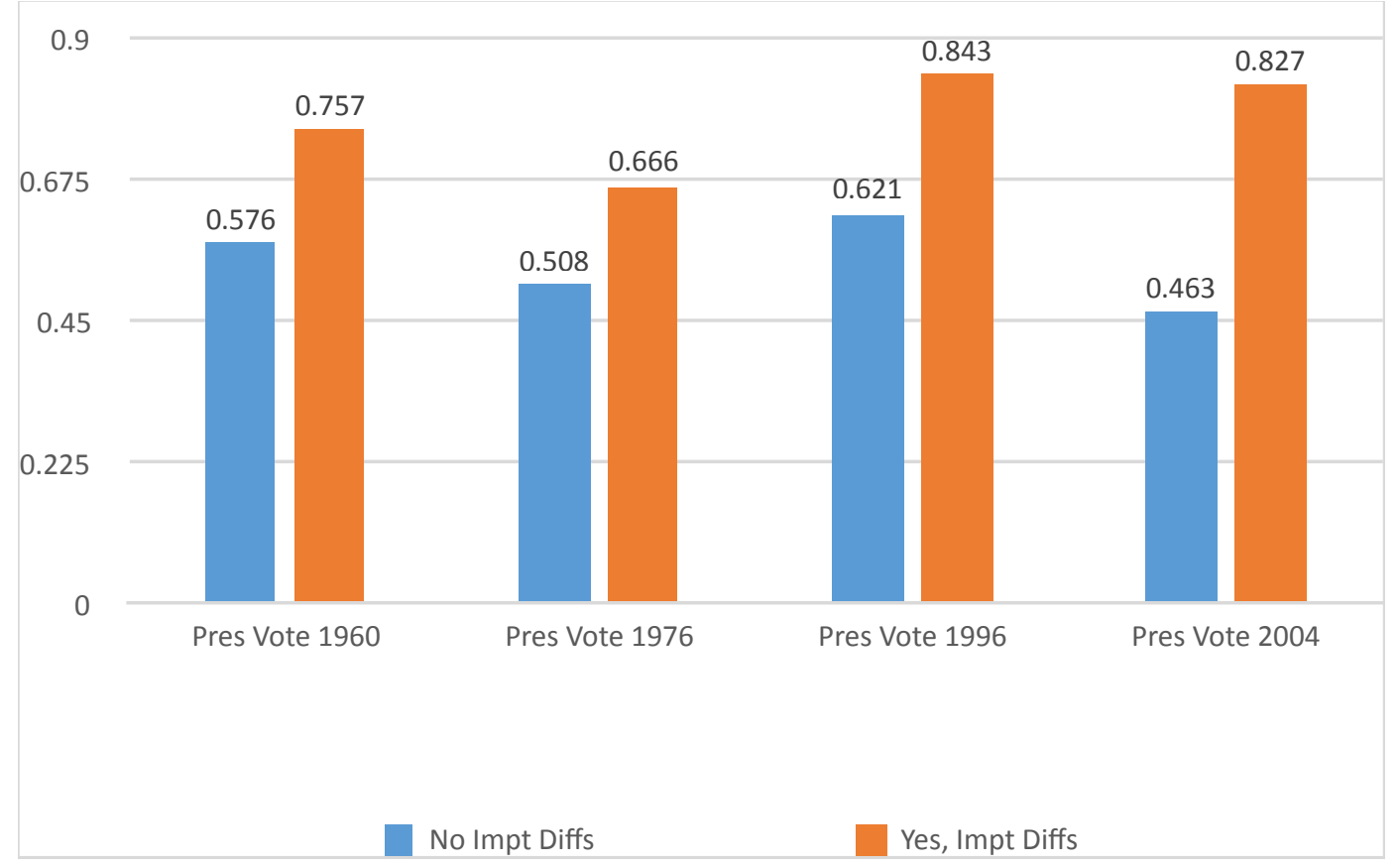


Figure 3b: $\mathrm{Tau}_{\mathrm{c}}$ correlations between Voter Choice ( $\mathrm{t}$ ) and Partisanship ( $\left.\mathrm{t}-4\right)$ by Perceptions of Party Differences

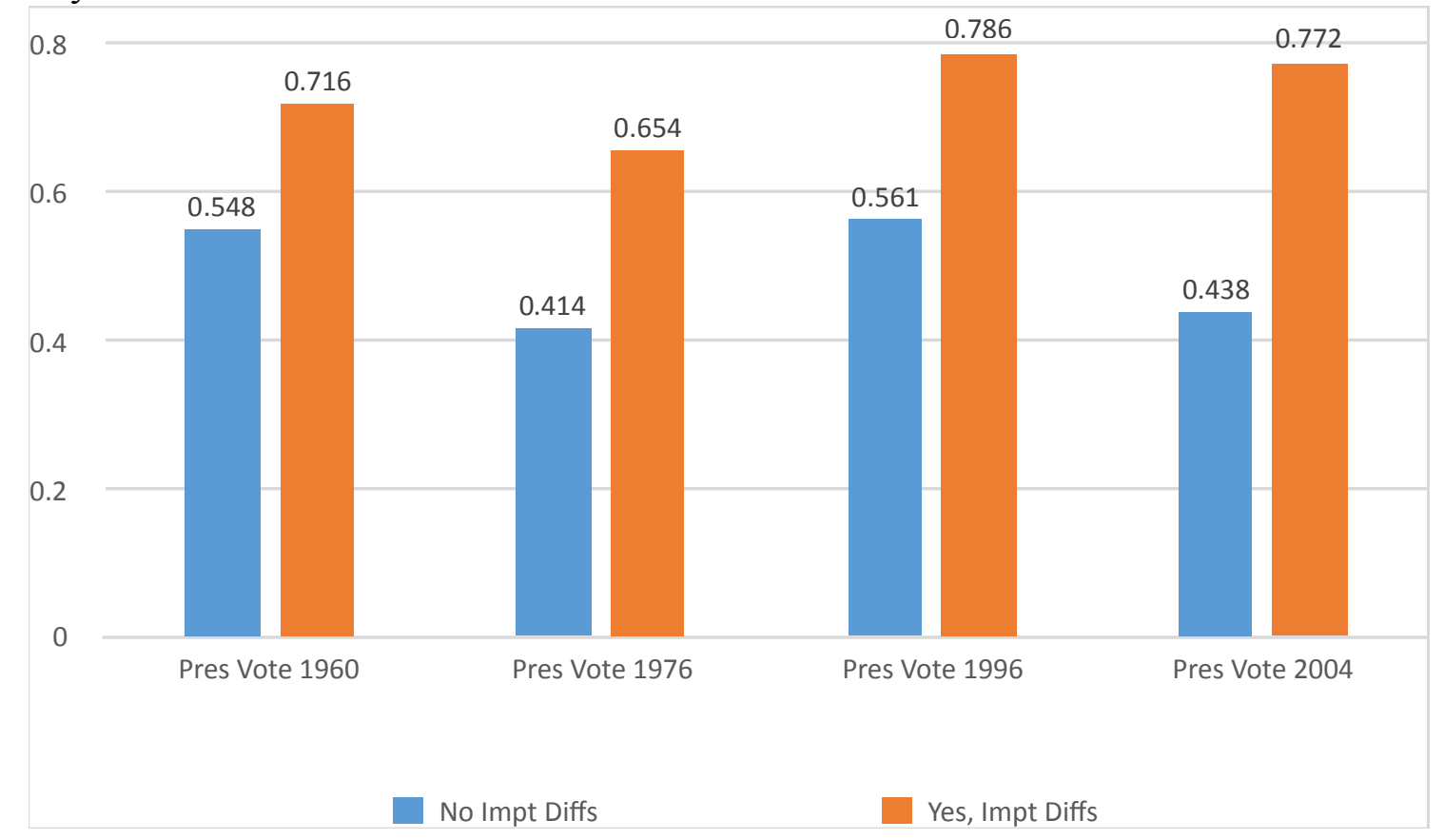

\section{The Long Term effects of Partisanship and Issues on Voter Choice}

Of course, partisanship never has been the whole story in explaining voter choice, either in the Michigan model or especially in the revisionist critiques. Issues, candidate evaluations, and retrospective evaluations all factor into the voter decision, and in the classical model, are all conditioned to some degree by partisanship. But, that raises the question: how powerful is partisanship as a long term force when compared to other factors? Issues that have been on the agenda for a long time, and particularly those that are ends-oriented and non-technical (Carmines and Stimson 1980), might rival partisanship as a long term influence on the vote choice, especially for young voters and those who may not see much of a difference between the parties on the issues that matter to them.

To investigate this possibility, I examine the associations between voter choice in 2004 and lagged (four years) measures of partisanship and two public policy questions: abortion and the tradeoff between government services and spending. Respondents were asked the standard ANES question about which position comes closest to their position on when a woman should be able to obtain a legal abortion, with four options ordered from "never permitted" to "in cases of rape, incest, or life of the mother" to "only when a clear need is established" to the most prochoice alternative, "always permitted". Face-to-face respondents were also asked to place themselves on a seven point scale, with endpoints labelled (1) fewer services, reduce spending and (7) more services, increase spending, while telephone respondents were asked whether they preferred increasing or decreasing services and spending, and whether they favored increasing or decreasing "a great deal" or "only some". Are issue preferences measured in 2000 as strong a predictor of voter choice in 2004 as partisanship measured in the same year? 
No, based on the $\mathrm{Tau}_{\mathrm{c}}$ statistics presented in Table 2. Because of the direction of the coding of the policy issues, the expected relationships between policy preferences and voter choice are negative (i.e., people with more restrictive preferences on abortion and those who favored fewer government services and less spending were more likely to vote to re-elect President Bush). Disregarding the signs, the magnitude of the relationship between voter choice and lagged partisanship (.681) is quite a bit stronger than for the relationship between voter choice and either abortion (-.330) or services/spending (-.368). As we've seen, the effects of partisanship as a long term force are weaker for younger voters and for those who do not see significant differences between the parties, but even among those voters, the long term association of partisanship and voter choice is stronger than the long term association of either issue and voter choice. The same is true as we look across categories of partisan strength; even among leaners and weak partisans, lagged partisanship trumps lagged issue preferences as a predictor of future vote.

Table 2: $\mathrm{Tau}_{\mathrm{c}}$ associations between

Voter Choice in 2004 and Partisanship and Issues in 2000

Party Id (7 pt) Abortion (4 pt) Services (7 pt)
All voters
0.681
$-0.330$
$-0.368$

Age $<35$

0.451

$-0.367$

$-0.200$

$35<=$ age $<50$

0.741

$-0.367$

$-0.507$

Age $>=50$

0.750

$-0.246$

$-0.375$

No Impt diffs (2000)

0.438

$-0.165$

$-0.256$

Yes, Impt diffs (2000)

0.772

$-0.408$

$-0.412$

Leaners (2000)

0.400

$-0.330$

$-0.145$

Weak Partisans (2000)

0.486

$-0.331$

$-0.259$

Strong Partisans (2000)

0.845

$-0.328$

$-0.635$ 
Lagged partisanship also holds its own in vote choice models that include contemporaneous measures of issue preferences and retrospective evaluations. Table 3 presents the results of two logistic regressions of the 2004 presidential vote. In the first model, vote choice is a function of two issues (abortion and services), two retrospective evaluation items (the traditional economic item and an item that asked respondents whether the war in Iraq was worth the cost), and partisanship, all measured in the 2004 wave of the panel. The second model retains the contemporaneous issue and retrospective measures, but partisanship is lagged four years. In both estimated models, partisanship, abortion, and the two retrospective evaluation items have strong and independent effects on the vote choice, but the spending/services item does not. ${ }^{4}$ As expected, when partisanship is lagged, it loses some of its predictive power to abortion and the retrospective items, but it is still a strong predictor of the vote even when controlling for those contemporaneous issue and retrospective attitudes.

To show the magnitude of the effects of partisanship, Figure 4 shows the predicted probabilities of voting for Bush for a median voter (someone who would allow abortion only with a clear need, placed him/herself at the midpoint of the services scale, thought the economy in 2004 was doing somewhat better, but did not think the Iraq War was worth the cost). If that voter had been a Weak Republican in 2000 , s/he would have had a $70.8 \%$ probability of voting to re-elect President Bush, in contrast to a Weak Democrat, who would have had only a 19.6\% probability of voting for Bush. Strong partisans in 2000 were even more loyal to their parties' nominees in 2004, as $81.2 \%$ of Strong Republicans (with those typical opinions) would have supported Bush, while only $12.1 \%$ of Strong Democrats with similar opinions would have done so. These results show that prior partisanship can weigh heavily on a cross-pressured, median voter.

But the 2004 election also serves as a reminder of how a powerful short term force - in this case, evaluations of the Iraq War - can overwhelm and condition the effects of other variables, including lagged partisanship. The sample of panel respondents was split almost down the middle on the question of whether the war had been worth the cost. For those who thought that it was, prior partisanship had limited independent effects on voter choice. Figure 4 also shows that if the portrait of our typical 2004 voter is changed to reflect someone who believed that the war was worth the cost, a Weak Republican in 2000 would have been nearly certain to have supported President Bush (98.5\% probability), and a Weak Democrat in 2000 would have also likely supported Bush (with $87.0 \%$ probability). Bush garnered very strong support from those who agreed with him that the war was worth the cost, and enough support based on other factors, including partisanship, from others to win reelection.

It is also important to remember that the coefficients shown in Table 3 (and in any multivariate model) represent the estimated effects of prior partisanship on voter choice, independent of the effects of retrospective evaluations and issue preferences. To the degree that prior partisanship actually conditions issue preferences and retrospective evaluations, the total effects of prior partisanship would be even greater. While multivariate models are vital to our understanding of the relative power of truly independent variables, bivariate relationships, as shown in Table 1 and Figures 1-3 of this paper, are also important in showing the total effects (direct and indirect) behind the association between two variables. 
Table 3: Logistic Regression of 2004 Presidential Vote on Party Identification, Issues, and Retrospective Evaluations

Model 1

Std

Variable

Intercept

Party Id 2004

$6=$ Strong Rep

Party Id $2000 \quad 6$ = Strong Rep

Abortion

2004

$4=$ Always

Permitted

Services $2004 \quad 7=$ More Services

$-0.004$

$0.119 \quad 0.972$

$-0.518$

$0.019 \quad 0.008$

$-0.623$

$0.184 \quad 0.007$

Iraq War

2004 $\begin{array}{lll}3.104 & 0.375 & 0.000\end{array}$

$1=$ Worth the cost
Model 2

Std

Coefficient Error $p(t)$

1.468

$1.003 \quad 0.144$
Economic

2004 $5=$ Much Worse

3.310

$0.345 \quad 0.000$

Number of cases

AIC 259.88

297.95

Figure 4: Likelihood of Voting for Bush (2004) by Party Identification (2000) and attitude on Iraq War (2004)

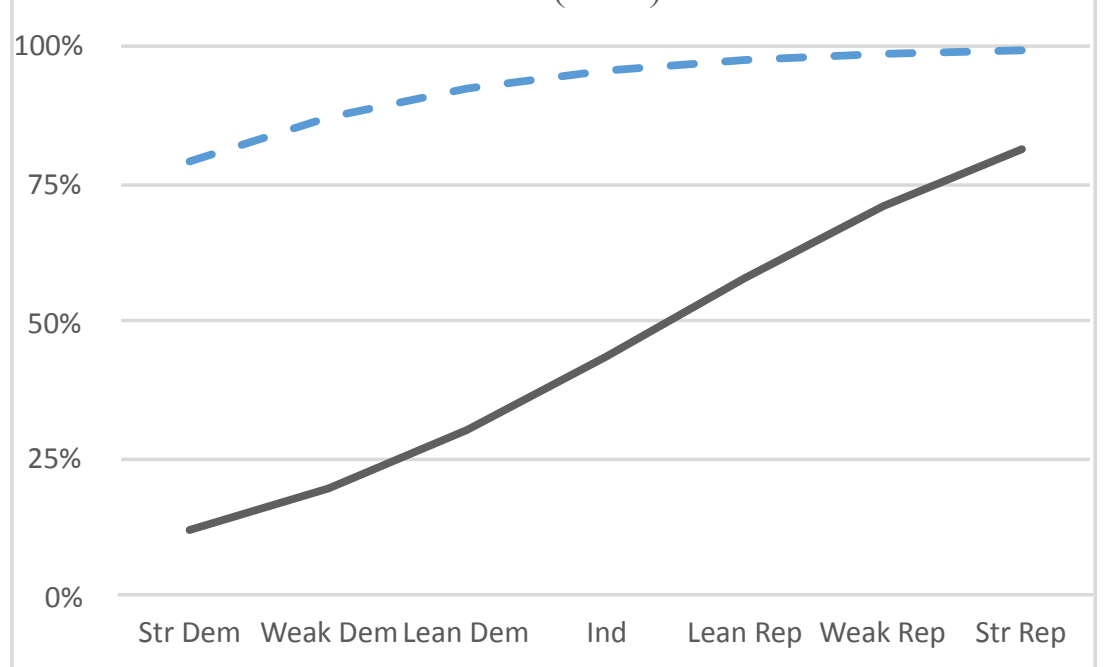




\section{Discussion}

The concept of party identification was central to the development of the Michigan model of voter behavior. While not immutable, most people learned partisanship as an affective orientation at their mother's knee (Langton and Jennings 1969), and maintained and strengthened that sense of belonging over the course of the life cycle. Revisionists would later argue about the empirics and meaning of this central concept, noting both more individual level and aggregate level change in partisanship than casual readers of The American Voter might have expected. That debate has generated lots of tests about the endogeneity of the party identification, as well as attempt to purge current issues and retrospective evaluations from measures of party identification via instrumental variables or multistage models.

That debate about a, perhaps the, core concept in voter behavior is important, but we should also not lose sight of the long-term value of partisanship. Whether partisanship is primarily an affective orientation, analogous to a sports fan's devotion to his or her team (Green, et al. 2002), a running tally of retrospective evaluations (Fiorina 1981), a cognitive shortcut summarizing past and current evaluations (Downs 1957), or something else, partisanship can have important stabilizing effects on the political system (Stokes 1966) and on individual behavior. In this paper, I have used four ANES panel studies spanning half a century to show that prior partisanship can still be considered a significant long term force in the current vote decision. Its value as a long term predictor varies across both settings and individuals, as convulsions in the party system appear to make it less valuable as a predictor, while increasing age and especially awareness of important differences between the parties renders it more valuable as a predictor of later behavior.

This analysis was based entirely on presidential vote choices in US elections, and future research could exploit the variations in party systems across borders to determine whether party identification has retained its value as a long term predictor in non-American settings that have panel data available, especially in multiparty systems and in new democracies where party systems that are still experiencing growing pains. 


\section{References}

Agresti, Alan. 1984. Analysis of Ordinal Categorical Data, Wiley Series in Probability and Mathematical Statistics Applied Probability and Statistics. New York: Wiley.

Aldrich, John H., and Richard G. Niemi. 1995. "The Sixth American Party System: Electoral Change, 1952-1992." In Broken Contract, ed. Stephen C. Craig. Boulder: Westview Press.

Bafumi, Joseph, and Robert Y. Shapiro. 2009. "A New Partisan Voter." Journal of Politics 71: $1-24$.

Bartels, Larry M. 2000. "Partisanship and Voting Behavior, 1952-1996." American Journal of Political Science 44: 35-50.

Blalock, Hubert M. 1972. Social Statistics. 2d ed, Mcgraw-Hill Series in Sociology. New York,: McGraw-Hill.

Campbell, Angus, Philip E. Converse, Warren E. Miller, and Donald E. Stokes. 1960. The American Voter. New York: John Wiley and Sons.

Carmines, Edward G., and James A. Stimson. 1989. Issue Evolution: Race and the Transformation of American Politics. Princeton, NJ: Princeton University Press.

- 1980. "The Two Faces of Issue Voting." American Political Science Review 74: 78-91.

Ceaser, James W., Andrew Busch, and John J. Pitney. 2009. Epic Journey: The 2008 Elections and American Politics. Lanham, Md.: Rowman \& Littlefield Publishers.

Converse, Philip E. 1976. The Dynamics of Party Support: Cohort Analyzing Party Identification. Beverly Hills: Sage.

Converse, Philip E., and Gregory B. Markus. 1979. "'Plus Ca Change:' the New Cps Election Study Panel." American Political Science Review 73: 2-49.

Craig, Stephen C. 1985. "The Decline of Partisanship in the United States: A Reexamination of the Neutrality Hypothesis." Political Behavior 7: 57-78.

Craig, Stephen C., and Michael D. Martinez. 1989. "Perceived Choice and Institutional Support: Limits to Rational Partisanship." Polity 21: 606-18.

Downs, Anthony. 1957. An Economic Theory of Democracy. New York: Harper and Row.

Fiorina, Morris P. 1981. Retrospective Voting in American National Elections. New Haven: Yale University Press.

Franklin, Charles H., and John E. Jackson. 1983. "The Dynamics of Party Identification." American Political Science Review 77: 957-73.

Green, Donald P., Bradley Palmquist, and Eric Schickler. 2002. Partisan Hearts and Minds : Political Parties and the Social Identities of Voters, Yale Isps Series. New Haven, Conn. ; London: Yale University Press.

Highton, Benjamin, and Cindy D. Kam. 2011. "The Long-Term Dynamics of Partisanship and Issue Orientations." Journal of Politics 73: 202-15.

Jennings, M. Kent, and Gregory B. Markus. 1984. "Partisan Orientations over the Long Haul." American Political Science Review 79: 1000-18.

Jennings, M. Kent, and Richard G. Niemi. 1981. Generations and Politics: A Panel Study of Young Adults and Their Parents. Princeton, N.J.: Princeton University Press. 
Jennings, M. Kent, and Laura Stoker. 2009. "Voting across Time and Generations." Paper presented at the Annual Meetings of the American Political Science Association, Toronto.

Johnston, Richard. 2006. "Party Identification: Unmoved Mover or Sum of Preferences?". Annual Review of Political Science 9: 329-51.

Keith, Bruce E., David B. Magleby, Candice J. Nelson, Elizabeth Orr, Mark C. Westlye, and Raymond E. Wolfinger. 1986. "The Partisan Affinities of Independent Leaners." British Journal of Political Science 16: 155-85.

Langton, Kenneth P., and M. Kent Jennings. 1969. "Mothers Versus Fathers in the Formation of Political Orientations." In Political Socialization, ed. Kenneth P. Langton. New York: Oxford University Press. 52-83.

Lewis-Beck, Michael S., William G. Jacoby, Helmut Norpoth, and Herbert F. Weisberg. 2008. The American Voter Revisited. Ann Arbor: University of Michigan Press.

MacKuen, Michael B., Robert S. Erikson, and James A. Stimson. 1989. "Macropartisanship." American Political Science Review 83: 1125-42.

Markus, Gregory B., and Philip E. Converse. 1979. "A Dynamic Simultaneous Equation Model of Electoral Choice." American Political Science Review 73: 1055-70.

Martinez, Michael D., and Michael M. Gant. 1990. "Partisan Issue Preferences and Partisan Change." Political Behavior 12: 233-54.

Miller, Arthur H., Warren E. Miller, Alden S. Raine, and Thad A. Brown. 1976. "A Majority Party in Disarray: Policy Polarization in the 1972 Election." American Political Science Review 70: 753-78.

Miller, Gary, and Norman Schofield. 2003. "Activists and Partisan Realignment in the United States." American Political Science Review 97: 245-60.

Miller, Warren E., and Teresa E. Levitan. 1976. Leadership and Change: The New Politics and the American Electorate. Cambridge, Massachusetts: Winthrop Publishers.

Miller, Warren E., and J. Merrill Shanks. 1996. The New American Voter. Cambridge, Mass.: Harvard University Press.

Niemi, Richard G., and M. Kent Jennings. 1991. "Issues and Inheritance in the Formation of Party Identification." American Journal of Political Science 35: 970-88.

Page, Benjamin I., and Calvin C. Jones. 1979. "Reciprocal Effects of Policy Preferences, Party Loyalties, and Vote." American Political Science Review 73: 1071-89.

Stokes, Donald E. 1966. "Some Dynamic Elements of Contests for the Presidency." American Political Science Review 60: 19-28.

Stonecash, Jeffrey M. 2006. Political Parties Matter : Realignment and the Return of Partisan Voting. Boulder, Colo.: Lynne Rienner Publishers.

Weinschenk, Aaron C. 2013. "Polls and Elections: Partisanship and Voting Behavior: An Update." Presidential Studies Quarterly 43: 607-17.

White, Theodore H. 1961. The Making of the President, 1960. [1st ed. New York: Atheneum Publishers. 


\section{Endnotes}

${ }^{1}$ The data were made available to the author by the American National Election Studies (http:// www.electionstudies.org/). ANES and the principal investigators of each of the panel studies bear no responsibility for any errors or omissions in my analyses of these data.

${ }^{2}$ While Agresti (1984: 173) does caution against comparing "values of measures calculated in tables having different dimensions or highly different marginal distributions," the comparisons here are based on tables with identical dimensions and with marginal distributions based on partisanship, which is still relatively stable in the aggregate over two and four year periods.

${ }^{3}$ In 1996, the difference between middle-aged and older voters is imperceptible at three decimal places.

${ }^{4}$ The coefficient on the spending/services item is significant when party identification is excluded from the model, suggesting that its effects are masked by the fact that preferences on redistributive issues are still strongly intertwined with party identification. 